\title{
Patriarchy and Gender Inequality in Education in Anambra State, Nigeria: A Sociological Underpinning
}

\author{
CHARLES CHUKWURAH MEZIE-OKOYE, PhD \\ Centre for Conflict and Gender Studies (CCGS), University of Port Harcourt, Port Harcourt, Nigeria
}

\begin{abstract}
From studies it is clear that what kept women where they are today are nothing but patriarchy. Patriarchy is the major obstacle to women's economic advancement and development. Despite differences in levels of domination the broad principles remain the same, i.e. men are in control. The nature of this control may differ but women are always at the receiving end. This write-up presents a comprehensive review of the progress in equal education for females in Nigeria especially in Anambra State. The Nigerian society is patriarchal in nature which is a major feature of a traditional society. It is a structure of a set of social relations with material base which enables men to dominate women. Women are therefore discriminated upon from, in most cases, acquiring formal education, mistreated and perpetually kept as house help; the average Nigerian woman is seen as an available object for prostitution, forced marriage, street hawking, instrument of wide-range trafficking and a misfit in the society. In Nigeria, it is observed that the womanhood is reduced to a mere infidel and a second-class citizen; hence, there is the commonality of general belief system that the best place for women is in the 'Kitchen'. This paper attempts to examine the conceptual and material bases of patriarchy and gender inequality in Anambra State, identifies dimensions of gender inequality and discrimination, and discusses socio-cultural and political factors leading to discrimination. The paper submits that all forms of inhuman discrimination and gender inequality must be challenged and opines for a deliberate, sensitive, consistent and systematic approach of gender relations this should include gender mainstreaming in all aspects of life. It was found that lack of mentoring, poor remuneration, women's lack of interest in academia, family responsibilities, the lengthy period of training, and the ideology that women should have low career aspirations due to traditional roles ascribed to them, accounted for the observed disparity in education. The implication of this disparity on the academic development of women is the general reduction in their research output and the perpetuation of their low status in academia. The study concluded that appropriate institutional adjustments and affirmation action programmes are necessary to meet women's demands of equality and improve retention.
\end{abstract}

Keywords: gender, inequality, patriarchy, gender Relations, gender discrimination, cultural norms

DOI: $10.7176 /$ RHSS/11-6-06

Publication date:March $31^{\text {st }} 2021$

\section{Introduction}

Patriarchy - men dominating society - points to social consequences of human reproduction, where male children are made to dominate female ones (Lerner, 1986; Friedl, 1990). In early human history, life was short and to balance the high death rate and maintain the population, women had to give birth to many children. This brought severe consequences for women. Because only females get pregnant, carry it for nine months, give birth, and nurse, women were limited in their activities for a considerable part of their lives. With a child at her breast or in her uterus, or one carried on her hip or her back, women were physically encumbered. Consequently, around the world women assumed tasks that were associated with the home and child care, while men took over the hunting of large animals and other tasks that required both greater speed and longer absences from the base camp (Huber, 1990).

As a result, men became dominant. Eventually, men took over society. Their sources of power were their weapons, items of trade, and knowledge gained from contact with other groups. Women became second-class citizens, subject to men's decisions. Men came to think of themselves as inherently superior - based on the evidence that they dominated society. They shrouded many of their activities with secrecy, and constructed elaborate rules and rituals to avoid "contamination" by females, whom they openly deemed inferior by that time. Even today, patriarchy is always accompanied by cultural supports designed to justify male dominance - such as designing certain activities as "not appropriate" for women. Male dominance in contemporary societies, then, is a continuation of a millennia-old pattern whose origin is lost in history.

The patriarchal society sets the parameters for women's structurally unequal position in families and markets by condoning gender-differential terms in inheritance rights and legal adulthood, by tacitly condoning domestic and sexual violence and sanctioning differential wages for equal or comparable work. Tradition or culture and religion have dictated men and women relationship for centuries and entrenched male domination into the structure of social organization and institution at all levels of leadership. Patriarchy justifies the marginalization of women in education, economy, labour market, politics, business, family, domestic matters and inheritance (Salaam, 2003). 
Gender refers to society's division of humanity, based on sex, into two distinctive categories. Gender guides how females and males think about themselves, how they interact with others, and what position they occupy in society as a whole. Thus gender also operates as a dimension of social inequality.

Gender inequality in education is regarded as the major impediment within the course of overall progression of the system of education. Therefore, it is vital to formulate measures and programs that are focused upon making provision of equal rights and opportunities to girls, not only within the course of acquisition of education, but also in the implementation of other job duties. The parents at home and teachers in school need to provide equal participation opportunities to girls. The main areas that have been taken into account are, factors causing gender inequality in education, factors influencing educational attainment, and programs promoting women's education (Kapur, 2019). Gender gaps favouring males - in education, health, personal autonomy, and more - are systematically larger in poor countries than in rich countries (Jayachandran, 2015).

Discrimination or inequality can emanate from an individual, group or a particular gender not having fundamental freedom, equal access to opportunities in political and public life as well as opportunities in education and employment. Invariably it affects the economic outcomes of equally productive workers based on the differential treatment on grounds of gender (Ezekwe, \& Enweani, 2019).

Discrimination in gender education is sort of a global phenomenon and not only present in Nigeria. In the words of Klasen \& Lamanna (2008), gender inequality is a persistent problem within the Indian society, especially for the girls, belonging to economically weaker sections of the society. It is true here in Anambra State as well as Nigeria in general. It is the children of the poor that are suffering this. This is more pronounced in the rural areas than urban areas. In rural areas of Anambra State, it is common to many girls that are not attending schools than boys. Most parents in the rural areas prefer to train the boy child in school than the girl child.

The imbalance which is permeating every fabric of our social setting is giving concern to our modern society. It has gradually developed into different manifestations with different names and meanings. Some call it gender discrimination others call it gender segregation. Most commonly it is referred to as gender inequality (Ezekwe, \&Enweani, 2019). This write-up attempts to examine the conceptual and material bases of patriarchy and gender inequality in Anambra State, identifies dimensions of gender inequality and discrimination, and discusses socio-cultural and political factors leading to discrimination.

\section{Statement of the Problem}

The word "patriarchy" has been recreated in the past two decades to analyse the origins and conditions of men's oppression of women (Kamarae, 1992). Originally used to describe the power of the father as head of household, the term 'patriarchy' has been used within post $1960 \mathrm{~s}$ feminism to refer to the systematic organization of male supremacy and female subordination (Kamarae, 1992; Stacey, 1993; Aina, 1998; etc.). The term has been defined as a system of male authority which oppresses women through its social, political and economic institutions. Feminists' theorists have argued that in any of the historical forms that patriarchal society takes, whether it is feudal, capitalist or socialist, a sex gender system and a system of economic discrimination operate simultaneously. They characterize patriarchy as an unjust social system that is oppressive to women. As feminist and political theorist Carole Pateman writes, "The patriarchal construction of the difference between masculinity and femininity is the political difference between freedom and subjection." (Carole 1988).

Okpe, (2005) submits that patriarchy is a broad network or system of hierarchical organization that cuts across political, economic, social, religion, cultural, industrial and financial spheres, under which the overwhelming number of upper positions in society are either occupied or controlled and dominated by men. Thus, any system that operationalizes an order that accords men undue advantage over women is considered patriarchal.

Patriarchy is a set of social relations which has a material base and in which there are hierarchical relations between men and solidarity among them which enable them in turn to dominate women. The material base of patriarchy is men's control over women labour power. That control is maintained by excluding women from access to necessary economically productive resources and by restricting women's sexuality.

There is still much gender inequality in Nigerian Education in spite of all steps taken by the Federal Government to give equal gender opportunity to education such as the provision of the Universal Free Primary Education (UPE) in 1976 and today, the Universal Basic Education (UBE). The female gender is still lacking behind in education and this has much implication in the social-economic status of the females in the nation. If drastic measures are not taken, tomorrow education in Nigeria may be all male affairs as the females dominate the markets, the farms and the homes to make more babies and increase poverty in the land (Omoregie, \& Ihensekhien, 2009).

\section{Aim and Objectives of the Study}

The aim of this study is to trace the origin of gender inequality in our society and why women are treated as 
second class citizens after all these years. The specific objectives are as follows;

(i) To examine the origin of patriarchy and why has it not withered away time.

(ii) To examine the causes of gender inequality in the education system in the study area.

(iii) To ascertain the implications of gender inequalities and discriminations in education in the study area.

(iv) To explore steps to be taken to normalize this discrimination in Anambra State Educational System?

\section{Research Questions}

1. What is the origin of patriarchy and why has it not withered away with time?

2. What are the causes of gender inequality in the educational system in the study area?

3. What are the implications of gender inequalities and discriminations in education in the study area?

4. What are the steps to be taken to normalise this discrimination in Anambra State Educational System?

\section{Study Area}

Old Anambra State was created in 1976 from part of East Central State, and its capital was Enugu. In 1991 a reorganisation divided Anambra into two states, Anambra and Enugu. The capital of Anambra is Awka.

Anambra is a state located in south eastern Nigeria. According to oral tradition, the title 'Anambra' is an anglicised version of the original title 'OmaMbala' which is the native name of the Anambra River which flows through the area being a tributary of the Niger River. The capital of the state is Awka. Onitsha, Ekwulobia, and Nnewi are the biggest commercial and industrial centres. Anambra state's slogan is "Light of the nation". Anambra state is among the 5 eastern Nigerian states. It is bounded by Delta state to the west, Imo State to the south, Enugu State to the east and Kogi State to the north. The biggest ethnic groups in this state are an Igbo speaking state ( $97 \%$ of the population) in the south-eastern part of Anambra state and 3\% of the population of Igala speaking people living mostly in the north-western part.

As mentioned above, most of the population (97 percent) of Anambra State are members of the Igbo group who are widely known for their determination and great love for entrepreneurship. The Anambra Igbo often move to other states of Nigeria and every region of the world. Wherever they live, their hard work, humility, and entrepreneurial spirit make them stand out in all their activities. That is why Anambra State has the motto: Light of the nation. The most popular fact about the Anambra state is that it is the most densely populated and the 2 nd most developed state in Nigeria after Lagos. The population growth rate in Anambra State is $2.31 \%$ per year, over $65 \%$ of people are living in the cities which make it one of the most urbanized places in Nigeria. Also, it has the highest literacy rate and the lowest poverty rate in Nigeria. There was a period in the country's history when most of the states could not pay the workers, but Anambra state was the only state even to increase workers salary. This is the first state where a female governor, Dame Virgy Etiaba, was elected. The most notable people coming from Anambra state include Nnamdi Azikiwe, Nigeria's first president; Nwafor Orizu, Nigeria's first senate president; Chief Alex Ekwueme, Nigeria's vice president; Chinua Achebe, one of the most popular African writers, and others.

\section{Theoretical Framework}

Three views have emerged in recent times as serious explanations of women exploitation and oppression which we have categorized as the materialist perspective, the radical feminist position and postmodernist approach. The materialist sees oppression of women as systematic and built into the structure of society. They see women's subordination as having a material base and a consequence of capitalism especially in a class society that is structured in hierarchical patriarchal relations. The argument of this group is grounded on two premises. The first is that women are socialized into low paying jobs. Secondly, women in addition to any paid labour that they may be engaged in do unpaid domestic labour outside capitalist relations of production. Domestic labour is not only unpaid but is also not computed by economist in calculating the GDP of counties. Meanwhile, domestic labour is necessary to oil the wheel of capitalism. The materialists argue that domestic work or housework is productive labour and a hidden source of profit for capitalism(Dalla\& James,1972). The criticism against the materialist conception which has its root in Marxism especially the orthodox ones is that there is too much emphasis on material factors and class analysis. In fact, some scholars argue that for most Marxists, it was unthinkable that working class men might be oppressors in their own homes or that 'bourgeois' women might also be oppressed (Delphy \& Leonard, 1992).

The radical feminists argue that women's subordination is not rooted in relations of production but in specific relations of reproduction and sexuality. They contend that housework can be looked at as reproducing and not producing labour power. Firestone, a radical feminist argued that 'unlike economic class, sex-class sprang directly from biological reality: men and women were created different, not equal' (Firestone, 1972). The position of the radical feminists has been criticized for putting too much emphasis on reproduction and sexuality. It gives the impression that women are subordinated mainly because of their role of giving birth to children. But we do know that the subordination of women goes beyond reproduction. Some scholars have pointed out that it 
is curious that feminists should 'succumb to such blatant biological determinism' (Jackson, 1999).

The postmodernists contend that women subordination results from the cultural construction of who a man or woman is. They argue that the use of word and language affect our psyche on the definition of men and women. They point to the effectiveness of the capacity of language to shape our thoughts and desires. Postmodernist conceptions of why women are oppressed has been criticized for neglecting the social context of power relations and failing to recognize the systematic oppressions of gender, class and race(Walby,1992).

\section{Literature Review}

Concept of Patriarchy

Patriarchy is a social system in which men hold primary power, predominate in the roles of political leadership, moral authority, special privilege and control of the property. They also hold power in the domain of the family, as fatherly figures. Historically, patriarchy has manifested itself in the social, legal, political, and economic organisation of a range of different cultures. The analysis of patriarchy and its effects is a major topic within the social sciences and humanities. Nowadays, patriarchy is a well-known term. It possesses everyday resonance, when used in casual conversation or a descriptive sense, whether, in English or any of the several languages spoken in the Indian sub-continent. At its simplest, the term means 'the absolute rule of the father or the eldest male member of the family over (Nirola, 2017). Even if not explicitly defined to be by their own constitutions and laws, most contemporary societies are, in practice, patriarchal (Lockard, 2007 \& Pateman, 2016).

The "appropriation of women's reproductive force" and the control of their bodies and their sexuality comes from radical feminism. For example, Shulamith Firestone discusses how human reproduction, which happens in women's bodies, is legally appropriated and controlled by men and is used to benefit men or to keep women at the mercy of men. Lidia Falcón considers women as a social and economic class, insisting that it is the father and/or husband who enforce the appropriation. Many feminists, such as Maria Meis and others, have spoken of the productive relationship between husband and wife in the modern nuclear family, which is similar to the relationship between a supervisor and a subordinate in the workplace. This subordination occurs in the private space of family because whatever the husband's produces enters the market (the privileged area of capitalist Patriarchy), while the wife's production is not. In this way, all of the wife's work in the non-privileged private space of the nuclear family is invisibilized (Facio, 2018).

\section{Patriarchy and Women's Subordination}

It is argued that the roles of men in the family are closely linked to the attributes of masculinity (Silvia, 1999). Studies on masculinity, mostly from the developed countries have revealed about five important conclusions (Short, 1996): that masculinity is not a biological category as much as a social construct subject to change, revision and multiple representations; that masculinity is not fixed, it is a relational, constantly shifting attribute defined in relation to the feminine; that masculinity is a site of interconnection and tension with other sources of social differentiation; that masculinity is both lived and imagined desires; and that masculinity is not only socially constructed and reconstructed, it is spatially grounded.

Regarding the existence and origin of patriarchy, traditionalists do believe that men are born to dominate and women to be subordinate. They believe that this hierarchy has always existed and will continue, and like other rules of nature this one too cannot be changed. There are others who challenge these beliefs and say that patriarchy is not natural it is man-made and, therefore, it can be changed.

One of the most difficult questions which have faced the study of masculinity in recent years has been actually defining the object of analysis (Collier, 1995). However, Brittan (1989) distinction between masculinity as an 'essence' and masculinism as an ideology is of use in the analysis of masculinity. According to Brittan, masculinism is the masculine ideology that justifies and naturalises male domination. As such, it is the ideology of patriarchy. Masculinism takes it for granted that there is a fundamental difference between men and women, it assumes that heterosexuality is normal, it accepts without question the sexual division of labour, and it sanctions the political and dominant role of men in the public and private spheres (Brittan, 1989:4).

Patriarchy, which pre-supposes the natural superiority of male over female, shamelessly upholds women's dependence on, and subordination to, man in all spheres of life. Consequently, all the power and authority within the family, the society and the state remain entirely in the hands of men. So, due to patriarchy, women were deprived of their legal rights and opportunities patriarchal values restrict women's mobility, reject their freedom over themselves as well as their property.

Subordination means, "Something else is less important than the other thing" (Cobuild, 2010:1559). According to Advanced Learners Dictionary, "subordination means having less power or authority than somebody else in a group or an organization” (Hornby 2003:1296). The term 'women's subordination' refers to the inferior position of women, their lack of access to resources and decision making etc. and to the patriarchal domination that women are subjected to in most societies. So, women's subordination means the inferior position of women to men. The feeling of powerlessness, discrimination and experience of limited self-esteem 
and self-confidence jointly contribute to the subordination of women.

Thus, women's subordination is a situation, where a power relationship exists and men dominate women. The subordination of women is a central feature of all structures of interpersonal domination, but feminists choose different locations and causes of subordination. Contemporary feminist theory begins with Simone de Beauvoir's argument that because men view women as fundamentally different from themselves, women are reduced to the status of the second sex and hence subordinate (Beauvior, 1974). Kate Millet's theory of subordination argues that women are a dependent sex class under patriarchal domination (Millet, 1977). Imagine my 30 year cousin who got married recently told me and my elder brother, how his advice could offer him advice. I asked him why your wife would not offer you an advice. He said if she tries that he will slap her. He told us that his wife has no right to offer him any advice; after all she is only a woman. Subjecting women to nothingness has been with our culture especially among the uneducated men.

Subordination is the situation in which one is forced to stay under the control of other. So women's subordination means the social situation in which women are forced to stay under the control of men. In this way to keep women under men's control, patriarchy operates some social customs, traditions and social roles by socialization process. To preserve the male supremacy, patriarchy created 'masculine' and 'feminine' characteristics, private-public realms by gendered socialization process (Sultana,

\section{Gender Inequality in Education}

Women across the world continue to suffer from gender inequality, including child- and forced marriage, gender-based violence, sexist policies, as well as barriers to participation in education and employment. Achieving gender equity globally is crucial to meeting development goals, reducing human suffering and solving our biggest environmental problems.

Education is said to be a vehicle that break the shackles of poverty thereby leading to transformation, development and progress(Ikoni,2009). With the 2005 MDGs' first deadline for attainment of gender parity in primary and secondary schools' enrolment already missed, the ability of women and girls to empower themselves economically and socially by going to school, or by engaging in productive and civic activities is still being constrained by their responsibility for everyday tasks in the household division of labour (CEC Report 2007).

In the present existence, there have been formulation of measures and programs that equal rights and opportunities should be made available to the girls. In the past, individuals possessed this viewpoint that male members of the family should be educated. When the males would acquire education, they would render a significant contribution in promoting goodwill and well-being of their families through attainment of employment opportunities. But, in the present existence, in urban as well as in rural communities, individuals and communities have brought about changes in their viewpoints and perspectives and are encouraging girls as well towards acquisition of education. Girls and women too can render an effective contribution in promoting welfare of their families and communities. When they obtain support from their parents, then they are able to attain good-quality education (Kapur, 2019).

Lack of education has been a strong visible barrier to female participation in the formal sector. The social pressures on females such as early marriages, and other extraneous factors as well as consideration of female education as secondary to that of boys and certain inhibitive religious practices in some parts of Nigeria are the major causes of the high illiteracy rate amongst women. As the impact of teenage pregnancy and early marriage makes abundantly clear, girls are at a double disadvantage in educational access, especially in the north, where these practices are most widespread (NDHS,2003).

Anambra State is a peculiar case when it comes to education and gender inequality. I can say that there is gender equality in education in Anambra State more than other States in Nigeria. More girls are school now more than ever. This because most parents especially non educated ones prefer to send their male children to learn trades and make money quick that going to school especially to secondary schools and tertiary institutions. Visit the Nnamdi Azikiwe University, Awka and you see that they are many women Heads of Departments and Professors than ever before in Anambra State.

\section{Discussion of Findings}

The origins of patriarchy are closely related to the concept of gender roles, or the set of social and behavioural norms that are considered to be socially appropriate for individuals of a specific sex. Much work has been devoted to understanding why women are typically thought to inhabit a domestic role while men are expected to seek professional satisfaction outside of the home. This division of labour is frequently mapped onto a social hierarchy in which males' freedom to venture outside of the home and presumed control over women is perceived as superior and dominant. As such, rather than working to destabilize the historical notion of patriarchy, much literature assess the origins of patriarchy or a social system in which the male gender role acts as the primary authority figure central to social organisation, and where fathers hold authority over women, 
children, and property. It implies the institutions of male rule and privilege and entails female subordination. These socio-biological theories of patriarchy are counterbalanced by social constructionist theories that emphasize how certain cultures manufacture and perpetuate gender roles. According to social constructionist theories, gender roles are created by individuals within a society who choose to imbue a particular structure with meaning. Gender roles are constantly toyed with and negotiated by actors subscribing to and questioning them. Since the feminist movement in the 1970s and the flood of women into the workforce, social constructionism has gained even greater traction (https:/courses.lumenlearning.com/cochise-sociology-os/chapter/the-origins-ofpatriarchy/).

Based on the available statistical data for primary, secondary and university enrolment we discovered higher percentage of male's enrolment at the different levels of education in Nigeria. There seems to be one underlying causative factor. It is the general preference by parents of male children to females. This higher level of preference is based on the traditional practice that male children will succeed their fathers and sustain their family. Also considering the limited resources of families such families prefer to lavish such meagre resources on their male children instead on female children that will become wives to other men and will no longer bear their family names.

This indicates that there is a gender dimension to educational attainment and development in Nigeria. According to the Examination Council of Nigeria (1994) there are still other problems, such as high dropout rates of female students, poor performance, reluctance on the part of female students to enrol in science-based courses and poor classroom participation. Across various geo-political delineations in Nigeria, a greater percentage of school-age girls are needlessly out-of-school, compared with the ratio applicable to boys of same age grouping (Adeniran \& Adebusuyi, 2007).

Various cultural and social values have historically contributed to gender disparity in education. According to work done by Denga, one prominent cultural view is that it is better for the woman to stay home and learn to tend to her family instead of attending school. The 'Nigerian tradition' was explained as a tradition that attaches higher value to a man than a woman, whose place is believed to be the kitchen. A study by the University of Ibadan linked the imbalance in boys' and girls' participation in schooling was to the long-held belief in male superiority and female subordination. This situation was further aggravated by patriarchal practices which gave girls no traditional rights to succession. Therefore, the same patriarchal practices encouraged preference to be given to the education of a boy rather than a girl. The Nigerian society (both historical and contemporary) has been dotted with peculiar cultural practices that are potently hurtful to women's emancipation, such as early/forced marriage, wife-inheritance and widowhood practices (Nmadu, 2009). At the beginning of colonialism and Christianity, rigid ideals about gender perceptions were imposed on the African mind. Thereafter, the woman's role has come to be limited to sexual and commercial labour; satisfying the sexual needs of men, working in the fields, carrying loads, tending babies and preparing food (Hammond \& Jablow, 1992). A major factor is the issue of male dominance in access to educational opportunities. The opportunity cost of foregoing school for female children is very high due to the male roles and society preference for male children.

Children's health is influenced by women's bargaining power in the home. Lower fertility rates, also associated with increased educational attainment for women, can have a positive effect on growth, while gender inequality in education undermines growth. This disparity has implications for educational and national development. The impact of gender inequality in education depends on the size of the differential and the disadvantaged sex involved at any level of education, which according to our results is mainly the female gender. Thus society will be richer in high level manpower the more women have access to education, because educating a female (a girl child) is educating the nation. Nations where women are denied access to education will continue to wallow in poverty and poor health. It takes education to imbibe health-culture and good sanitization. These illiterate mothers will continue to perpetuate their ignoramus to their children both males and females.

There is a need to make education compulsory especially for the girl-child. Every girl-child must be made to be registered in school and be made aware of the importance of education for the future. This is because most of these young girls do not know that education is the best empowerment anybody can give them.

\section{Conclusion}

This research has shown that there is persistence of gender inequality in Nigeria at all levels of education. The reasons for this ugly situation have been traced to be historical, cultural, traditional and the patriarchal structure of the society. Education of the girl child is one of the first steps in a process of enabling her to take control over her own life, participate on an equal basis in the society and freeing herself from economic exploitation and patriarchal oppression.

From all indications, capitalism and patriarchy are the major causes for women's sexual inequality, or gender imbalance in different areas of social and economic endeavours. In every sphere of life, women and girls have worse life opportunities than men especially in underdeveloped economies, and so it is in Anambra State. 
Iloegbunsim (2006), said education, is a weapon for social development, equity and justice. Providing women with equal opportunity for education would foster the repositioning of women socially, economically and even politically since women are mothers of tomorrow's nation.

\section{Recommendations}

For Nigeria and Anambra State to eliminate the issue of gender inequality in education in Nigeria, the following conscious efforts should be made in order to address the issue:

(i) All cultural and traditional practices, which may tend to enhance gender inequality in education, should be discouraged at all levels of education.

(ii) There is urgent need for the Federal, State and local governments to give financial assistance through scholarships or bursaries to female students.

(iii) Laws against early marriage that hinder the females to read and pursue education should be promulgated by governments to see that such practices are stopped henceforth.

(iv) Laws also should be promulgated on quota system for 50:50 in admission of males and females in all schools in Anambra State institutions of learning from primary to tertiary level.

(v) Girls and parents should be made aware that education of the girl-child is the best empowerment to be given them for the betterment of their future.

(vi) Education must be made compulsory and free for all girls in Anambra State by the State government and anybody that violates it must be punished.

\section{REFERENCES}

Adegun, A. O. (2012). Gender Factor and Labour Participation among Academic Staff in Tertiary Institutions in Ekiti State, Nigeria. European Journal of Educational Studies 4(2): 249-258.

Adeniran and Adebusuyi, I. (2007). "Educational Inequalities and Women's Disempowerment in Nigeria" Department of Sociology, University of Lagos, Nigeria

Akanle, O. (2011). The Sociology of Gender Equality and Development and Development in Democratizing Nigeria.The Nigerian Journal of Sociology and Anthropology. 9. Pp. 22-36.

Akanle, O. and Olutayo, A.O. (2012). Gender and Poverty Eradication in Nigeria: Women's Right the Missing Link. East African Journal of Human Rights. 18 (1), pp. 227-241.

Beauvior, D. S. 1974. The Second Sex. Vintage Books: New York.

Brittan, A. (1989). Masculinity and Power.Oxford Blackwell.

CEC Report (2007). Gender Equality and Women's Empowerment in Development Cooperation, Commission of European Communities, (SEC(2007) 332), Brussels, March 2007.

Cobuild, C. (2010). Advanced Illustrated Dictionary. Harper Collins Publishers Ltd.: Great Britain.

Collier Richard (1995). Masculinity, Law and the Family London: Routledge.

Egunjobi, O. A. (2008). Women in Academics: The untold story of Gender Inequality and Discrimination against Women in the Ivory Tower. Lead Paper presented at the seminar organized by the National Association of women in Academics (NAWACS), University of Ado-Ekiti Chapter, AdoEkiti.

Gberevbie, D.E., Osibanjo, A.O., Adeniji, A.A. and Oludayo, O.A. (2014). An Empirical Study of Gender Discrimination and Employee Performance among Academic Staff of Government Universities in Lagos State, Nigeria. International Journal of Social, Human Science and Engineering, 8 (1), pp. 101-109.

Hacker, H. (1972). 'Women as a Minority Group' in N. Glazer-Malbin and H.Y. Waehrer (eds) Woman in a Man-Made World. London: Hienemann.

Hammond, D. and Jablow, A. (1992). The Africa that never was, Prospect Heights. Woveland Press.

Hornby A. S. 2003. Oxford Advanced Learner's Dictionary. Oxford University Press: New York.

Huber, J. (1990). Macro-micro links in gender stratification: 1989 presidential address. American Sociological Review, 55, $1-10$.

Ikoni, U.D. (2009). The Challenges of Poverty in a Globalised World: Perspective on the Nigerian Situation. Longman publishers

Jayachandran, S. (2015). The Root of Gender Inequality in Developing countries. Annual Review of Economics, Northwestern University, Evanston, Illinois 60208.

Klasen, S. (2002). Low schooling for Girls, slower growth for all. World Bank Economic Review, 16

Klasen, S. and Lamanna, F. (2008). The Impact of Gender inequality in Education and Employment on Economic Growth in Developing countries: Updates and extensions. World Bank Economic Review 16

Lerner, G. 1989. The Creation of Patriarchy. Oxford University Press: New York.

Maruzani, N. (2013). Gender Discrimination in Retail Shops' Personnel: The Case of General Dealer Shops at Murambinda Growth Point, Buhera, Zimbabwe. International Journal of Asian Social Science, 3(3): pp. 669-681.

Mensah, D.O., Biney, I.K., Ashong, G.A. (2009). Gender Issues that Impinge on Access and Equity of the 
Master's Programme in the Institute of Education, University of Ghana. International journal of Higher Education Research.1(1).

Millett, K. 1977. Sexual Politics. London: Virago

Nmadu, T. (2009). "On Our Feet: Women in Grassroot Development", in Journal of Women in Academics, Vol. 1 No 1, Sept. 2000, JOWACS Pp. 165-171.

Nigeria Demographic and Health Survey, 2003, Maryland: ORC.

Ogbogu, C. (2009a). Gender Inequality In Academia: Evidences From Nigeria. Contemporary Issues In Education Research - September 2011 Volume 4, Number 9

Olaogun, J.A., Adebayo, A.A., \& Oluyemo, C.A. (2015). Gender Imbalance in Academia in Nigeria. European Scientific Journal November 2015 /SPECIAL/ edition ISSN: 1857 - 7881 (Print) e - ISSN 1857- 7431

Olowa, O., and Adeoti, A., (2014). Effect of Education Status of Women on Their Labour Market Participation in Rural Nigeria American Journal of Economics 2014, 4(1): $72-81$ DOI: 10.5923/j.economics.20140401.07 http://article.sapub.org/10.5923.j.economics.20140401.07.html

Oluwagbemiga E. Adeyem, Kolawole E Odusina and Akinwole E Akintoye (2016). Religion and Labour Force Participation in Nigeria: Is there any Inequality among Women? African Journal of Reproductive Health 2016 https://www.ajrh.info/index.php/ajrh/article/view/172/0

Proshare (2018). Informal Economy and Poverty Reduction i

Postkitt, E. (1999). Women in Higher Education.University System News. Vol. 9(2):34-56.

Salaam, T. (2003). A Brief Analysis On The Situation Of Women In Nigeria Today, DSM.

Short, J.P. (1996). The Urban Order: An Introduction to Cities, Culture and Power. Blackwell U.S.A

Silvia Necchi (1999). "Men, family formation and reproduction" Policy and Research Paper No. 17, IUSSP.

World Bank (2001).Engendering Development. Washington, D.C: The World Bank. 